\title{
Spatial, relational and affective understandings of citizenship and belonging for young people today: Towards a new conceptual framework
}

\author{
Bronwyn E Wood \\ Victoria University of Wellington, Wellington, New Zealand
}

\section{Rosalyn Black}

Deakin University, Melbourne, Australia

\section{Introduction}

Belonging is 'at once a feeling, a sense and a set of practices' (Wright, 2015, p.392)

The past two decades have seen a growing focus within educational policy, practice and research on young people's citizenship and their role within the democratic project. More recently, we have also seen an emerging interest in belonging as a key aspect of young people's citizenship (Arnot \& Swartz, 2012; Harris, 2015a; Mitchell \& Parker, 2008). This is not a new or surprising idea as citizenship is 'always tied up with questions of belonging' (Abu El-Haj \& Bonet, 2011, p.31) or, indeed, of not-belonging. What has changed, however, is how young people experience citizenship and belonging.

Increased global flows of both ideas and people, and the 'fluidity of membership' (Baumann, 2016, p. 23) that now characterise many of the world's largest urban centres, have disrupted the traditional bonds between identity, citizenship and place. Traditionally, the grounds for inclusion as a citizen who belongs were predicated on a close sense of attachment to a territorial place and on static notions of space, territoriality and boundary making associated with the nation-state. Marshall's (1950) historic analysis of citizenship defined this traditional notion of citizenship as the legal status and associated rights and duties of those who are full members of a community. His understanding was predicated upon the principle that all citizens are not only equal before the law, with equal access to opportunities for democratic participation and contribution, but that they feel that they belong - or have a place - within the democratic 
process. His understandings were also built on essentialist conceptions of the collective and the duties and responsibilities associated with that collective.

More recently, however, this Marshallian notion of citizenship has been subject to extensive criticism, especially for its lack of consideration for gender, race, socio-economic status and transnational affinities. Put simply, his thesis has been critiqued for failing to capture the complex and multidimensional experience of being a citizen and of belonging in society in the 21 st century. While the old notions and configurations of citizenship remain strongly entrenched in the practices and operation of the nation-state and its institutions, these need to be expanded to include more flexible and expansive understandings of who is a citizen that consider, for example, those who cannot contribute to work, taxation or military service, such as the unemployed, the disabled, children and migrant workers (Lister, 2007) as well as those who sense of citizenship is no longer tied exclusively to the nation-state. These new notions of citizenship are needed to encompass the intensified social relations and new affinities, identifications, loyalties and animosities (Isin, 2008) that now occur not only within the nationstate, but also beyond the nation-state as a result of changes associated with new communication and transport technologies which have enabled global flows of capital, labour and people.

These shifting configurations of time, space and mobility as a result of globalisation have significant implications for how we conceptualise belonging and citizenship today and hold particular implications for young people whose identities are forged in such contexts. Young people today grow up with more-than-local politics (Mitchell \& Parker, 2008), but are still heavily influenced by policies and practices associated with nations and communities. It is not that we can simply replace the national with the global and reproduce container-like models of political space - instead, we need much more dynamic and flexible notions of space itself, especially if citizenship identities and practices are relational (Hörschelmann \& Refaie, 2014). In particular, the changing social and spatial affinities enabled by globalising processes have destabilised traditional notions of citizenship, and have thrust the affective and relational concept of belonging much more overtly onto centre stage.

Citizenship and belonging are often used in interchangeable ways - as Antonsich notes, 'belonging is used as a synonym of or in association with the notion of citizenship' (2010, p. $645)$ - but very little work has untangled the closely woven associations between these two terms, or considered what this might mean for how we understand young citizens today. 
Citizenship has, in fact, been characterised as subject to an 'exclusionary impasse' in relation to belonging (Deiana, 2013, p. 184), serving as a marker of exclusion as much as inclusion. The need for much more expansive understandings of citizenship and belonging, and for a greater understanding of citizenship as belonging, is evident from a range of recent analyses (e.g. Abu El-Haj, 2015; Harris, 2010; Isin, 2008; Kallio \& Mitchell, 2016; Youkhana, 2015; Yuval-Davis, 2006, 2007; Yuval-Davis, Anthias, \& Kofman, 2005).

This chapter presents a review of recent work which profiles new and broadened concepts of citizenship and belonging and which reflects the complex relations that young people have with others, circulating objects, artefacts and changing social, political and cultural landscapes. As a result, we propose a fresh examination of the spatial, relational and affective dimensions of citizenship and belonging and a reconsideration of what these dimensions mean for young people today. Our argument is structured around three propositions which emerge from the contemporary literature in this area.

The first proposition is that space matters. Citizenship, and the cultural, political and social affiliations and identifications that attend it, are not geographically neutral nor free-floating but have always been 'formed through scalar configuration and engagement with place' (Desforges, Jones, \& Woods, 2005, p. 444). Foucault's assertion that the present epoch would be 'above all the epoch of space' (1986, p. 22) has borne some ripe theoretical and empirical fruit. People's identification with multiple and differently scaled and situated communities, and affiliations with transnational networks and new publics actors, means that a fixed and territorial-based definition of citizenship is no longer adequate (Kallio \& Mitchel, 2016). Crucially, the implications of these global and spatial shifts and how they shape the relationship between space and the geographies of belonging and citizenship in globalised times requires further development (Cuervo \& Wyn, 2014; Farrugia, 2014; Gieryn, 2000; Harris, 2015b).

A second and closely related way in which we argue for a reinvigoration of the concepts of citizenship and belonging is through a focus on relationships. Experiences of belonging and citizenship are constituted at the intersection with others. They are a part of what Arendt refers to as the 'web of human relationships' (1958, p. 183). This proposition highlights the significance of young people's connections to other people - both adult and young peers, near and far - and how these relationships shape their experiences of citizenship and belonging. 
A third and final dimension, and almost inseparable from a focus on relationships, is a much closer focus on the significance of affect and emotion in citizenship acts and dispositions (Arnot \& Swartz, 2012; Black, 2017b; Bondi \& Davidson, 2011). While experiences of identity and belonging 'quiver with affective energy' (Thrift, 2004, p. 57), the significance of emotion in citizenship has often been neglected. Yet, as Osler and Starkey (2005) argue, while citizenship is about status and practice, it is mostly first experienced as a feeling. Importantly, it may not always be a warm and fuzzy feeling of attachment. There is evidence that citizenship action can also happen as a result of feeling dislocated, angry or discontented - consider the many protest movements of recent years such as Occupy, the Arab Spring protests or the Spanish Indignados, for example. This dimension seeks to highlight the integral role of affect in citizenship and belonging and how this provides fresh insights into young citizens today.

The goal of this chapter, therefore, is to seed fresh understandings of citizenship and belonging that better recognise their spatial, relational and emotional dimensions for young people. The intended outcome is a more dynamic and expansive notion of citizenship and belonging as characterised by more flexible social membership (Isin \& Turner, 2007) in keeping with how young people actually live as citizens today. The chapter proceeds with an examination of the theoretical traditions which have informed contemporary shifts in understandings of citizenship and belonging. We combine this with an examination of recent literature which has drawn attention to the significance of spatial, relational and affective dimensions of citizenship and belonging for young people. While we present these as three separate dimensions, we recognise that much of the literature collapses these together, whether by examining relational and affective, or spatial and affective aspects of belonging and citizenship simultaneously. We have somewhat artificially drawn them out as separate dimensions for the purpose of developing this conceptual framework, although our empirical examples show that these ideas often intersect. We conclude by considering the implications of this approach and highlights the growing significance of belonging as an associated concept when studying youth citizenship in an increasingly globalised and transnational world.

\section{Theoretical origins}

The move towards more spatial, relational and affective understandings of citizenship and belonging has not emerged as an isolated endeavour. Alongside the growth of transnationalism and globalisation which has triggered a more fluid sense of citizenship, a set of broader shifts and theoretical turns have sparked new ways of seeing and knowing across many disciplines. 
Before we examine the evidence for fresh understandings of citizenship, we review briefly some of the broader theoretical shifts. In particular, we consider the influence of feminist and cultural studies on youth citizenship, and the emergence of more everyday understandings of citizenship and belonging heralded by the affective turn (Bondi, Davidson, \& Smith, 2005; Clough \& Halley, 2007).

Key critiques of fixed notions of citizenship stem from feminist and cultural studies which argue that we need understandings of citizenship which take into account the identities of those traditionally excluded from the public sphere - such as women, children, the disabled and minority groups (Deiana, 2013; Dyck, 2005; Lister, 2007; Smith, 1987). Lister's (2007) work, for example, interrogates citizenship's universalistic and normative claims from the perspective of marginalised groups and nation-state 'outsiders' in order to advance much more differentiated forms of citizenship. Drawing on the seminal work of Fraser (2003), Young (1990) and other feminist writers, Lister argues that a more inclusive and flexible notion of citizenship is needed which includes the ability for all members of society participate equally and achieve social esteem or recognition and more explicitly recognise diversity of expressions and understandings of citizenship.

A further critique in feminist theorising has centred on traditional binaries which pay disproportionate attention to formal and public (male-dominated) expressions of social life, thus overlooking the 'hidden places' (Dyck, 2005) of the domestic and the ordinary. Along with a number of other theoretical traditions (including queer, Marxist, postcolonial, anti-racist, cultural and other critical theorists), such analyses have sought to bring to light the embodied, everyday and informal practices of traditionally disempowered people. A focus on the everyday also characterises wider traditions within sociology (Jacobsen, 2009; Smith, 1987), geography (Lefebvre, 1971) and political studies (Fraser, 2003) which seek to expose ways in which the state is enmeshed in the ordinary and to demonstrate the political possibility of such spaces (Staeheli, Ehrkamp, Leitner, \& Nagel, 2012). Attention to the everyday therefore has been a significant aspect of recent work on children and young people's citizenship practices. It has drawn attention to how everyday actions that previously went under the radar could be considered 'political' (Kallio \& Häkli, 2011; Lister, 2003; Wood, 2012, 2015). In so doing, it has contributed to a re-working of the notion of the political and of citizenship.

A further and associated theoretical area which has influenced how we understand citizenship and belonging can be described as the 'affective turn' (Clough \& Halley, 2007). While 
emotional studies have long been the focus of psychologists, this turn has drawn attention to aspects of emotion and affect from across the disciplines (Bondi, 2005). Such studies have critiqued Cartesian duality and previous understandings of emotion as separate from actions or rationale thought - a point also reinforced by feminist authors (Boler, 1999). They are associated with a scholarly focus on embodiment, performativity (Butler, 1990) and an integrated understanding of mind, body, feelings and actions which occur with almost seamless feedbacks (Wetherell, 2015).

The theoretical implications for citizenship and belonging are twofold: firstly, that feelings of belonging (or not belonging) are inseparable from the experience of being a citizen (Mitchell \& Parker, 2008; Osler \& Starkey, 2005), and secondly, that these feelings need to be understood within the context of specific emotional geographies and locations (Bondi et al., 2005; Wright, 2015). Such ideas have shifted our thinking about citizenship away from something that is constituted through status, rights and responsibilities and towards something that includes and occurs through geographically embedded practices at the intersection of social relationships (Hörschelmann \& Refaie, 2014; Kallio \& Mitchell, 2016). We proceed by tracing some of the seminal literature that has responded to these broader theoretical shifts and that have contributed to the advancement of more spatial, relational and affective understandings of young people's citizenship and belonging.

\section{Place, citizenship and belonging}

There is a large corpus of scholarship which understands belonging as 'an inherently geographical concept' (Mee \& Wright, 2009, p. 772) and which seeks to highlight the complexity and nuance of individuals' relationships and experiences of citizenship and belonging within specific geographical places. Within the sociology of youth scholarship, for example, there is a growing awareness of the importance of place for young people and a growing use of spatial analyses (Cuervo \& Wyn, 2013; Farrugia, 2014). This shift addresses what Farrugia describes as 'the invisibility of spatial processes in young people's lives' (Farrugia, 2014, p. 293). It has been spearheaded by emerging research evidence which carefully traces the close links between space and citizenship experiences or practices, and how these links have changed in recent times.

One key component of this examination of place characterises the impact of an increasingly globalised world upon traditional notions of the individual and the state. Increased movements 
and flows of people have contributed to the prospect of 'living permanently with variety and difference' (Bauman, 2016, p. 24). New flows of data, images, media, goods, information and people have contributed to a growing interest in the 'cosmopolitanisation' of citizenship which Beck defines as the 'erosion of distinct boundaries dividing markets, states, civilisations, cultures, and not least of all the lifeworlds of different peoples' (2007, p. 1). This draws into question the bonds between identity and citizenship, individual and place, neighbourhood and belonging. It prompts a more global and layered understanding of citizenship that is characterised by flexible and multiple notions of identity and rights beyond the nation-state (Beck, 2007; Isin \& Turner, 2007; Osler \& Starkey, 2005; Ronkainen, 2016).

Conversely, other studies have led to the growing recognition that despite the multiple mobilities of the globalised world, a sense of local connectedness still shapes young people's experiences of citizenship. As Harris and Wyn (2009) observe, it is within the 'micro-territories of the local that young people may form their strongest sense of belonging and citizenship' (p. 327). Goodwin and Young's (2013) study of social housing neighbourhoods in urban Sydney, for example, found that children and young people had a deep knowledge of their local community and were concerned about how issues such as violence, homelessness, transport and employment affected it. Osler and Starkey (2003) similarly found strong affective ties amongst young people in culturally diverse Leicester. Young people appear strongly motivated to enact or practice their citizenship at the local level whether through established modes such as volunteering or through other modes such as advocacy, protest or social change projects (Hart, 2009; Wood, 2012). These acts, and the desire for membership and recognition that attends them, are often founded upon everyday relational practices, a dimension of citizenship and belonging that we turn to next.

\section{Relationships, citizenship and belonging}

The previous section of our chapter highlighted how young people's citizen identities and actions are inseparable from specific geographic contexts. These sites are not 'flat' static 'landscapes', but are the product of complex interlocking and non-interlocking networks of relations at every scale (Massey, 1992). Space is relational. Massey argues that we need to view space as the product of 'the simultaneous coexistence of social interrelations and interactions at all spatial scales, from the most local level to the most global' (p. 80). Citizenship and belonging need to be seen, therefore, as dynamic and inseparable products of 
both spatial and relational practice. They are 'experiences of being part of the social fabric' (Anthias, 2006, p. 21).

A focus on the relational aspect of citizenship enables a more ecological and interconnected understanding of young people's experiences of citizenship and belonging within their communities and through their interrelationship with others. For many young people, citizenship and belonging is contingent on being made welcome within 'a community of membership' (Anthias, 2006, p. 21). Even in urban communities characterised by high socioeconomic disadvantage, culturally diverse young people may describe a climate of 'cohesion, connection and belonging' that is made possible within their community precisely because of the diversity that characterises it (Harris, 2015a, p. 7).

Alternately, they may describe experiences of 'unbelonging', such as those of recently arrived young Sudanese immigrants in a rural Australian school and community (Edgeworth, 2014, p. 351). Edgeworth describes how insider discourses construct rurality and belonging in very specific, hegemonic and historic ways that render Black students' bodies and cultures 'out of place' $(2014$, p. 362) in the places in which they seek to belong. More than this, Edgeworth argues, it is the place itself - the geography of the rural, with its attendant homogeneity, small population and located history - which intensifies the experience of exclusion for young people who are so easily seen as different. This research highlights the mutuality of spatial and social effects on citizenship experiences - and how they serve to reinforce a sense of un/belonging. It also highlights the way in which the characteristics of place may assert a reified notion of citizenship that is attached to a homogenous racial, linguistic and historical identity - one which excludes those who are not seen to be part of its legacy.

A relational perspective on citizenship enables us to grasp how the political sphere intersects closely with interpersonal relationships and connections (Hörschelmann \& Refaie, 2014). As global displacement escalates as a result of social, economic and cultural upheavals, young people often bear the brunt of such changes. In just one example of many, Rios-Roja describes the efforts of young immigrants in Catalonia to find a place of belonging in a legal and discursive environment that is as likely to revile them as risky aliens as it is to welcome them as potential citizens (Ríos-Rojas, 2011). These and other accounts of the experience of particular young people in particular places and times highlight the contested and conditional nature of citizenship and belonging not only for those young people but also for vast numbers of other young people forced to be 'out of place' in search of economic and social membership 
and security. Perceptions of young people as 'risky' results in limited social interaction and trust with others and therefore decreases meaningful connections and inclusion. Such experiences of lack of relationship also contribute to shaping young people's experiences of citizenship and belonging.

Relationships with adults are significant in our understandings of young people's citizenship and belonging. An intergenerational focus can show how adults can regulate and control the citizenship actions and sense of belonging of young people. Baker for example, describes the experience of young graffiti writers on the socioeconomically disadvantaged geographical peripheries of a large city (Melbourne) who find themselves caught between such categories as 'art or vandalism, professional or amateur, artist or criminal, and legitimate or illegitimate citizens' (2015, p. 997). On the one hand, these young people are part of a legal program run by the local government, a program which invites them to contribute to the creative identity of the local community and to have a legitimate presence within the local democratic process. On the other, they remain at risk of criminalisation and encounters with police under the state government's graffiti prevention legislation. Intergenerational spaces can also be supportive of children and young people's citizenship identities and actions.

In other examples of support within intergenerational spaces, Wood (2015) found that the actions of teachers played a significant role in the type of active citizenship young people took within citizenship education programmes. Teachers supported or restricted young people's awareness of social issues and in turn, the nature of the social action that they took to address that issue. Teachers therefore played a key role in shaping the locally or globally-focused citizenship identities and spatial orientations of their students as a result. Similarly, Black (2015) has highlighted the importance of interpersonal relations in young people's education for citizenship, illustrating the challenges and risks faced by teachers who champion citizenship education programmes in the face of conflicting or competing education discourses and priorities.

Relational experiences also shape young people's mobility in ways which contribute to their acceptance and belonging as citizens in society. Webb and her colleagues (2015) added a temporal dimension to their exploration of young people's belonging in low socioeconomic rural locations by looking at the role that such places play in shaping young people's future aspirations. Their interviews with young people in four Australian rural communities highlight the tensions that can exist between young people's desire to move to the city in pursuit of higher 
education and other positional opportunities, and the 'pull of home' that often sees them return to their rural town or village once they have completed their studies (Webb et al., 2015, p. 34). They suggest that while rural young people find the attraction of education, work and travel to distant places very appealing, their sense of attachment to their local place, as well as the value of the close-knit relationships they experience within it, are ultimately more important and more seductive. In some instances, in fact, young rural people's grounded sense of their local places, and of the freedom, safety and social connectedness that they associate with those places, may preclude their willingness to explore the possibilities that urban spaces may have to offer (Farrigua, 2014; Gill \& Howard, 2006). Bourdieu's (1977) notions of social and cultural capital are also strongly founded on relationships and illustrate the significance of family resources, assets and learned dispositions (habitus) in shaping practice.

\section{Affect, citizenship and belonging}

The final dimension that we argue requires attention for contemporary understandings of young people's citizenship and belonging is that of affect. As we propose in the introduction, traditional concepts of citizenship and belonging have a number of limitations when it comes to examining how young people feel about being part of a society. Schmitt (2010), for example, describes how Turkish young people who were born in Germany and who held full status as German citizens felt that they would 'never be German' but would remain as 'foreigners' throughout their lives there.

This draws into question many studies of citizenship which assume that legal status constitutes citizenship belonging. Such approaches 'serve to naturalise socially produced, situational and contextual relations, converting them to taken-for-granted, absolute and fixed structures of social and personal life'. In so doing, they 'gloss over the fissures, the losses, the absences and the borders within them' (Anthias, 2006, p. 21). Many of these experiences are felt more than seen. Attention to more affective dimensions of citizenship and belonging provide deeper insights about how young people feel about their experiences of being a citizen and their sense of attachment and connection to places and people.

An examination of emotion and affect provides a way of bringing together the other two dimensions of citizenship and belonging which we have presented in this chapter. In particular, a focus on affective and emotional connections to the geographies of place provides a powerful lens for examining young people's citizenship actions and dispositions. As discussed earlier, a 
sense of attachment to a specific space or place can be a powerful factor behind young people's acts of care towards that place, fuelled by a desire to protect, preserve and transform it (Bartos, 2013; Black, 2017a; Goodwin \& Young, 2013; Harris, 2015b; Osler \& Starkey, 2003; Wood, 2013).

Emotions of belonging to a place are not fixed or static but are a fluid and constantly re-forming spatial relationship, or in Bartos' words, 'a process, one that is created through the coming and going of agents, through the repetition of norms, stories and experiences shared in place, and entangled in a web of socioeconomic and ecologic relationships spanning across both geographic space and time' (2013, p. 89). Moreover, affective dimensions are constituted within and between social relations and interactions and cannot be understood in isolation of these. Our second dimension of social relationships therefore is enhanced through the addition of an affective gaze which examines how affect is distributed: 'it is an in-between, relational phenomenon' (Wetherell, 2015, p. 158). Belonging can be understood as a reflection therefore of not just a deeply personal individual experiences, but of a form of 'collective identity or citizenship' (Antonsich, 2010, p. 647).

An affective gaze also provides a way to understand the experience of many young people who find themselves holding affective affiliations to more than one nation or location. A number of recent studies of transnational young people illustrate collective and hybrid aspects of belonging - and young people as a result experience a high degree of flux, fluidity and conditionality in their citizenship and sense of belonging (or not belonging) (e.g. Abu El-Haj \& Bonet, 2011; Arnot \& Swartz, 2012; Yuval-Davis, Anthias, \& Kofman, 2005). Many transnational young people feel included as citizens - recognised and capable of action - within one aspect of a place or period of time but not another.

Such experiences relate closely to the emotional experience of inclusion and exclusion. For example, Abu El Haj and Bonet (2011) describe how young people from Muslim, transnational communities living in living in New York after 9/11 found themselves positioned as outsiders, even though they were legally Americans. This challenged their sense of belonging as the political conditions for substantive inclusion in American society were absent. However, the research also found that these same young people still actively worked to challenge and reshape US culture and politics, as well as forming affiliations and commitment to the global community of Muslims and other imagined communities. These ideas highlight the significance of studying affect as an integral dimension of citizenship and belonging, and 
holding much more flexible notions of citizenship which match the range of ways which young people experience being citizens.

\section{Conclusion}

Recent refugee flows in the Middle East and Europe demonstrate the complexity of citizenship today where state systems continue to play an enduring role in controlling and regulating citizens' legal status, whilst at the same time struggling to cope with new forms of transnational citizenship, affiliations and belonging (Kallio \& Mitchell, 2016). At a time when global flows and flux are stripping away its traditional meanings, associations and promises, it may be time for a new language and a fresh understanding of citizenship. At the same time, we need understandings which recognise that old configurations of citizenship formation among young people still exist alongside the new.

In this chapter, we have argued that such new understandings should be strongly shaped by spatial, relational and affective dimensions and that a focus on these dimensions offers an opportunity to embrace more flexible, hybrid and inclusive aspects of citizenship and belonging. Our argument began from a geographic starting point by highlighting how globalising and transnational practices and processes have impacted upon traditional conceptions of space and therefore upon citizenship, identity and belonging. In particular, we have suggested that shifts in spatial flows and social interactions have enabled a much more fluid form of citizenship in which 'the state and national polity no longer appear as the selfevident loci of citizenship' (Kallio \& Mitchell, 2016, p. 259). We have argued that a new vocabulary of citizenship is needed to explain these new times, and suggested that an integrated framework of spatial, relational and emotional dimensions of citizenship and belonging could provide this.

Through a spatial, relational and emotional analysis of youth citizenship, belonging has emerged as an indispensable dimension of citizenship in contemporary times - and arguably as a 'thicker' concept than citizenship (Yuval-Davis, Anthias, \& Kofman, 2005, p. 526). By focusing on belonging alongside citizenship, we gain a richer and more insightful way of thinking about young people's role in contemporary society that goes beyond idea of membership, rights and duties, and beyond forms of identification with other people (Anthias, 2006). We also gain a way of thinking about the everyday social places in which citizenship is 
lived, 'along with the feelings of being part of a larger whole and with the emotional and social bonds that are related to such places' (Anthias 2006, p. 20).

This does not mean, however, that citizenship no longer has value as an analytical tool. Citizenship has always been 'a mark of belonging and commitment to a specific place' (Desforges et al., 2005, p. 440), 'a set of relationships by which membership is constructed through physical and metaphorical boundaries and in the sites and practices that give it meaning' (Staeheli, 2011, p. 394). We have argued that the affective and relational aspects of young people's relationship to place may be as powerful in shaping their experience of citizenship as the nature of the places themselves.

Youkhana (2015b, p. 20) articulates the importance of 'approaching belonging from what is performed as belonging and how it is enacted in certain situations'. We would like to extend this contention and suggest that especially in complex socio-geographic contexts, young people's belonging should be understood in terms of what is experienced and performed as belonging (affective), how such emotions arise and flow between people (Bondi, 2005) and create the conditions for citizenship and belonging (relational), and how this is enacted in specific places (spatial). Just as 'notions of belonging are often based on an inside/outside dichotomy' (Youkhana, 2014, p. 172), so notions of place are often based on a here/there (or here/not here) dichotomy. Both of these dichotomies conceal the nuances of young people's feelings and experiences of local belonging and citizenship.

The normative conception of citizenship which characterises most education policy and practice reflects and perpetuates 'an abstract notion of belonging' (Kennelly \& Dillabough, 2008 , p. 494) that does little to reflect the ways in which citizenship and belonging are experienced by specific young people in particular places. We need to promote a better understanding of the multidimensional nature of young people's citizenship and belonging as an experience that is situated, relational and conditional, 'one that is both spatially and temporally precarious and subject to change depending on the context in which the individual finds him or herself' (Wood \& Black, 2014, p. 63). We also need to promote a better understanding of it as an ensemble experience that is 'always in a process of becoming, rather than an end state' (Staeheli, 2005, p. 198). The fluidity and transnationalism of contemporary times and space mean that the changing spatial, relational and affective nature of young people's citizenship and belonging needs to be reflected in our current understandings of youth but also in educational policy, practice and research. 


\section{References}

Abu El-Haj, T. R. 2015. Belonging in troubling times: Considerations from the vantage point of Arab American immigrant youth. In J. Wyn \& H. Cahill (Eds.), Handbook of children and youth studies (pp. 433-445). Singapore: Springer.

Abu El-Haj, T. R., \& Bonet, S. W. 2011. Education, Citizenship, and the Politics of Belonging: Youth From Muslim Transnational Communities and the "War on Terror". Review of Research in Education, 35(1), 29-59. doi:10.3102/0091732x10383209

Arendt, H. 1958. The human condition. Chicago: The University of Chicago Press.

Arnot, M., \& Swartz, S. 2012. Youth citizenship and the politics of belonging: Introducing contexts, voices and imaginaries. Comparative Education, 48(1), 1-10.

Anthias, F. 2006. Belongings in a globalising and unequal world: Rethinking translocations. In N. Yuval-Davis, K. Kannabiran, \& U. Vieten (Eds.), The Situated Politics of Belonging (pp. 17-32). London: SAGE Publications Ltd.

Antonsich, M. 2010. Searching for belonging - An analytical framework. Geography Compass, 4(6), 644-659. doi:10.1111/j.1749-8198.2009.00317.x

Arnot, M., \& Swartz, S. 2012. Youth citizenship and the politics of belonging: introducing contexts, voices, imaginaries. Comparative Education, 48(1), 1-10.

Baker, A. M. 2015. Constructing citizenship at the margins: the case of young graffiti writers in Melbourne. Journal of Youth Studies, 18(8), 997-1014. doi:10.1080/13676261.2015.1020936

Bartos, A. E. 2013. Children sensing place. Emotion, Space and Society, 9, 89-98.

Bauman, Z. 2016. Living in an age of migration and diasporas. In P. Ahponen, P. Harinen, \& V.-S. Haverinen (Eds.), Dislocations of civic and cultural borderlines (pp. 21-32). Switzerland: Springer.

Beck, U. 2007. A new cosmopolitanism is in the air. Literaturen, November 2007.

Black, R. 2015. Between policy and a hard pedagogical place: the emotional geographies of teaching for citizenship in low socioeconomic schools. Pedagogy, Culture \& Society, 120. doi:10.1080/14681366.2014.994664

Black, R. 2017a. Active Citizenship in Australian Schools. In: Peterson, A. \& Tudball, L. (eds.) Civics and Citizenship Education in Australia: Challenges, Practices and International Perspectives. London: Bloomsbury.

Black, R. 2017b. Making the Hopeful Citizen in Precarious Times. In: Campbell, P., Hickey, C. \& Kelly, P. (eds.) Young People and the Politics of Outrage and Hope. Amsterdam: Brill. 
Boler, M. 1999. Feeling power: Emotion and education. NY: Routledge.

Bondi, L., \& Davidson, J. 2011. Lost in Translation. Transactions of the Institute of British Geographers, 36(4), 595-598.

Bondi, L. 2005. Making connections and thinking through emotions: Between geography and psychotherapy. Transactions of the Institute of British Geographers, 30(4), 433-448.

Bondi, L., Davidson, J., \& Smith, M. 2005. Introduction. In J. Davidson, L. Bondi, \& M. Smith (Eds.), Emotional Geographies (pp. 1-16). Aldershot/Burlington: Ashgate.

Bourdieu, P. 1977. Outline of a theory of practice (R. Nice, Trans.). Cambridge: Cambridge University Press.

Butler, J. 1990. Gender trouble: Feminism and the subversion of identity. London: Routledge.

Clough, P., \& Halley, J. 2007. The affective turn. Durham, NC: Duke University Press.

Cuervo, H., \& Wyn, J. 2014. Reflections on the use of spatial and relational metaphors in youth studies. Journal of Youth Studies, 17(7), 901-915. doi:10.1080/13676261.2013.878796

Deiana, M.-A. 2013. Citizenship as (not) belonging? Contesting the replication of gendered and ethnicised exclusions in post-Dayton Bosnia-Herzegovina. Beyond Citizenship? (pp. 184-210): Springer.

Desforges, L., Jones, R., \& Woods, M. 2005. New geographies of citizenship. Citizenship Studies, 9(5), 439-451.

Dyck, I. 2005. Feminist geography, the 'everyday', and local-global relations: Hidden spaces of place-making. The Canadian Geographer, 49(3), 233-243.

Eckert, J. 2011. Introduction: subjects of citizenship. Citizenship Studies, 15(3-4), 309-317.

Edgeworth, K. 2014. Black bodies, White rural spaces: disturbing practices of unbelonging for 'refugee'students. Critical Studies in Education(ahead-of-print), 1-15.

Fallov, M. A., Jørgensen, A., \& Knudsen, L. B. 2013. Mobile Forms of Belonging. Mobilities, $8(4), 467-486$.

Farrugia, D. 2014. Towards a spatialised youth sociology: The rural and the urban in times of change. Journal of Youth Studies, 17(3), 293-307. doi:10.1080/13676261.2013.830700

Fraser, N. 2003. Social justice in the age of identity politics: Redistribution, recognition and participation. In N. Fraser \& A. Honneth (Eds.), Redistribution and recognition? A political-philosophical exchange. London/NY: Verso.

Gieryn, T. F. 2000. A Space for Place in Sociology. Annual Review of Sociology, 26(1), 463496. doi:doi:10.1146/annurev.soc.26.1.463 
Gill, J., \& Howard, S. 2006. Revisioning the Social: Young Australians and the Rural/Urban Divide. Citizenship Teaching and Learning, 2(1), 66-78.

Goodwin, S., \& Young, A. 2013. Ensuring Children and Young People Have a Voice in Neighbourhood Community Development. Australian Social Work, 66(3), 344-357.

Harris, A. 2010. Young people, everyday civic life and the limits of social cohesion. Journal of Intercultural Studies, 31(5), 573-589. doi:10.1080/07256868.2010.513424

Harris, A. 2015a. Belonging and the uses of difference: young people in Australian urban multiculture. Social Identities, 1-17.

Harris, A. 2015b. Transitions, cultures and citizenship: Interrogating and integrating youth studies in new times. In D. Woodman \& A. Bennett (Eds.), Youth cultures, transitions and gernations: Bridging the gap in youth research (pp. 84-98). Houndshill/NY: Palgrave Macmillan.

Harris, A., \& Wyn, J. 2009. Young people's politics and the micro-territories of the local. Australian Journal of Political Science, 44(2), 327-344.

Harris, A., Wyn, J., \& Younes, S. 2010. Beyond apathetic or activist youth: 'Ordinary' young people and contemporary forms of participation. Young, 18(1), 9-32.

Hart, S. 2009. The 'problem' with youth: young people, citizenship and the community. Citizenship Studies, 13(6), 641-657. Retrieved from 10.1080/13621020903309656

Hörschelmann, K., \& Refaie, E. E. 2014. Transnational citizenship, dissent and the political geographies of youth. Transactions of the Institute of British Geographers, 39(3), 444456. doi:10.1111/tran.12033

Isin, E. 2008. Theorising acts of citizenship. In E. Isin \& G. M. Nielsen (Eds.), Acts of citizenship (pp. 15-43). London/NY: Palgrave Macmillan.

Isin, E., \& Turner, B. 2007. Investigating citizenship: An agenda for citizenship studies. Citizenship studies, 11(1), 5-17.

Isin, E., \& Wood, P. K. 1999. Citizenship and identity. London: Sage.

Jacobsen, M. 2009. Introduction: The everyday: An introduction to an introduction. In M. Jacobsen (Ed.), Encountering the everyday: An introduction to the sociologies of the unnoticed. Houndsmill: Palgrave MacMillan.

Jones, G., \& Wallace, C. 1992. Family, youth and citizenship. Buckingham: Open University Press.

Kallio, K. P., \& Häkli, J. 2011. Tracing children's politics. Political Geography, 30, 99-109.

Kallio, K. P., \& Mitchell, K. 2016. Introduction to the special issue on transnational lived citizenship. Global Networks, n/a-n/a. doi:10.1111/glob.12113 
Kennelly, J., \& Dillabough, J. A. 2008. Young people mobilizing the language of citizenship: struggles for classification and new meaning in an uncertain world. British Journal of Sociology of Education, 29(5), 493-508.

Lefebvre, H. 1971. Everyday life in the modern world. The Athlone Press: London.

Lister, R. 2003. Citizenship: Feminist perspectives (2nd ed.). London: Macmillan.

Lister, R. 2007. Inclusive citizenship: Realising the potential. Citizenship studies, 11(1), 4961.

Massey, D. 1992. Politics and space/time. New Left review, 196, 65-84.

Marshall, T. H. 1950. Citizenship and social class. Cambridge: Cambridge University Press.

May, V. 2011. Self, Belonging and Social Change. Sociology, 45(3), 363-378.

Mee, K., \& Wright, S. 2009. Geographies of belonging. Environment and Planning A, 41(4), 772-779. Retrieved from http://www.envplan.com/abstract.cgi?id=a41364

Mitchell, K., \& Parker, W. C. 2008. I pledge allegiance to...Flexible citizenship and shifting scales of belonging. Teachers College Record, 110(4), 775-804.

Osler, A., \& Starkey, H. 2003. Learning for cosmopolitan citizenship: Theoretical debates and young people's experiences. Educational Review, 55(3), 243-254.

Osler, A., \& Starkey, H. 2005. Changing citizenship: Democracy and inclusion in education. Maidenhead: Open University Press.

Ríos-Rojas, A. 2011. Beyond Delinquent Citizenships: Immigrant Youth's (Re)Visions of Citizenship and Belonging in a Globalized World. Harvard Educational Review, 81(1), 64-94.

Ronkainen, J. 2016. Contents of citizenship? Multiple citizens' orientations towards nationality and different forms of citizenship. In P. Ahponen, P. Harinen, \& V.-S. Haverinen (Eds.), Dislocations of civic cultural borderlines (pp. 33-56). Switzerland: Springer.

Schmitt, I. 2010. 'Normally I should belong to the others': Young people's gendered transcultural competences in creating belonging in Germany and Canada. Childhood, 17(2), 163-180. doi:10.1177/0907568210365643

Shaheed, F. 2007. Citizenship and the Nuanced Belonging of Women. In J. Bennet (Ed.), Scratching the Surface: Democracy, Traditions, Gender (pp. 23-38). Lahore: Heinrich Böll Foundation.

Sloam, J. 2014. New Voice, Less Equal: The Civic and Political Engagement of Young People in the United States and Europe. Comparative Political Studies, 47(5), 663-688.

Smith, D. E. 1987. The everyday world as problematic: a feminist sociology. Boston: Northeastern University Press. 
Staeheli, L. A., Ehrkamp, P., Leitner, H., \& Nagel, C. R. 2012. Dreaming the ordinary: Daily life and the complex geographies of citizenship. Progress in Human Geography, 36(5), 628-644. doi:10.1177/0309132511435001

Staeheli, L. A. 2005. Editorial: Can American Cities be Sites of Citizenship? What Can we do About it? Urban Geography, 26(3), 197-199. doi:10.2747/0272-3638.26.3.197

Staeheli, L. A. 2011. Political geography: where's citizenship? Progress in Human Geography, 35(3), 393-400. doi:http://dx.doi.org/10.1177/0309132510370671

Thrift, N. 2004. Intensities of feeling: Towards a spatial politics of affect. Geografiska Annaler, $86 B(1), 57-78$.

Vromen, A., \& Collin, P. 2010. Everyday youth participation? Contrasting views from Australian policymakers and young people. Young, 18(1), 97-112. doi:10.1177/110330880901800107

Webb, S., Black, R., Morton, R., Plowright, S., \& Roy, R. 2015. Geographical and place dimensions of post-school participation in education and work. Retrieved from Adelaide:

Wetherell, M. 2015. Trends in the turn to affect: A social psychological critique. Body \& Society, 21(2), 139-166. doi:10.1177/1357034x14539020

Wood, B. E., \& Black, R. 2014. Performing citizenship Down Under: Educating the active citizen. Journal of Social Science Education, 13(4). doi:10.2390/jsse-v13-i4-1413

Wood, B. E. 2012. Crafted within liminal places: Young people's everyday politics. Political Geography, 31(6), 337-346. doi:10.1016/j.polgeo.2012.05.003

Wood, B. E. 2015. Participating as young citizens in diverse communities. In J. Wyn \& H. Cahill (Eds.), Handbook of Children and Youth Studies (pp. 405-417): Springer Singapore.

Wood, B. E. 2015. A genealogy of the "everyday" within young people's citizenship studies. In K. P. Kallio \& S. Mills (Eds.), Politics, Citizenship and Rights Volume 7 of Skelton, T. (Editor-in-Chief) Geographies of Children and Young People (Vol. 7, pp. 1-14): Springer Singapore.

Wright, S. 2015. More-than-human, emergent belongings: A weak theory approach. Progress in Human Geography, 39(4), 391-411. doi:10.1177/0309132514537132

Youkhana, E. 2014. Creative Activism and Art Against Urban Renaissance and Social Exclusion-Space Sensitive Approaches to the Study of Collective Action and Belonging. Sociology Compass, 8(2), 172-186.

Youkhana, E. 2015. A conceptual shift in studies of belonging and the politics of belonging. Social Inclusion, 3(4). doi:http://dx.doi.org/10.17645/si.v3i4.150

Young, I. M. 1990. Inclusion and democracy. Oxford: Oxford University Press. 
Yuval-Davis, N., Anthias, F., \& Kofman, E. 2005. Secure borders and safe haven and the gendered politics of belonging: Beyond social cohesion. Ethnic and Racial Studies, 28(3), 513-535. doi:10.1080/0141987042000337867

Yuval-Davis, N. 2006. Belonging and the politics of belonging. Patterns of Prejudice, 40(3), 197-214.

Yuval-Davis, N. 2007. Intersectionality, citizenship and contemporary politics of belonging. Critical Review of International Social and Political Philosophy, 10(4), 561-574. doi:10.1080/13698230701660220 